\title{
SUBPRIME LENDING AND ITS IMPACT ON SOCIO ECONOMIC GROWTH IN INDIA
}

\author{
ABISHEK GOEL \\ Bal bharai public school pitampura, 28 Deepali Pitampura New Delhi 110034 \\ DOI: 10.46609/IJSSER.2021.v06i06.002 URL: https://doi.org/10.46609/IJSSER.2021.v06i06.002
}

\begin{abstract}
Subprime Loans are those provided to individuals and companies who have a background in inability or difficulty in paying back the loan amount. Such loans are usually provided on highinterest rates, poor quality of collaterals, and less favorable terms for the borrower as they have a higher risk of defaulting the loan.

With many owning sole trading licenses or freelancing jobs, preferring cash transactions to pay lower taxes, and not maintaining proper paperwork, the population of India seems like a lucrative market for subprime lenders. While we already see many large financial corporations like Citi, Bandhan, Yes Bank entering the Indian market between 2010 to 2018, the ongoing recession caused due to the Covid-19 pandemic can act as a catalyst for subprime lending growth within the country.

This paper focuses on the Growth of Subprime lending within India and its effect on the socioeconomic growth of the country. By looking into the history of subprime lending and its implication on the national economies then, we can identify

Through our research we identify there is a lot of potential subprime loan borrowers in India and there could be a crisis just like it happened in us in 2008 if India does not follow the necessary steps and protect its economy from the default rates of these type of loans which is no the rise due to covid 19 and the ongoing lockdown.
\end{abstract}

\section{RESEARCH METHODOLOGY}

While there are many various forms of research methods that can be used to provide insight into the situation smaller sports are in. I have used the Secondary Research approach considering the amount of data available and the lockdown throughout the various states. 


\section{International Journal of Social Science and Economic Research}

ISSN: $2455-8834$

Volume:06, Issue:06 "June 2021"

Secondary Research is a systematic analytical investigation where I would rely on the data available on the subject. As I shall be using Data available online, I have ensured that I use data presented by reliable sources and media channels only.

This format of research is not only cost \& time-effective, gathering data from reliable sources ensures the authenticity of the data. Using this form of research also allows me an opportunity to identify any knowledge gaps which could be used to serve as the basis of further systematic investigation.

\section{LITERATURE REVIEW}

- Federal Reserve History: the article looks into the history of banking systems across the globe and how the Subprime mortgage crisis affected the strongest economy.

- The first twenty years of the European Central Bank: monetary policy: The article provides a comprehensive view of the ECB's monetary policy over these two decades.

- Subprime Mortgage Crisis, Its Timeline and Effect: The paper provides a chronological history of Subprime lending and how it feeds the demand formortgage-backed securities sold through the secondary market.

- Corporate Finance Institute- Credit Analysis Process: The paper looks into credit analysis process refers to evaluating a borrower's loan application to determine thefinancial health of an entity and its ability to generate sufficient cash flows to service the debt

- The Risk of Subprime Mortgages by a New Name: the paper looks into why Subprime lending has been directly connected to the Great Recession

- The Subprime Mortgage Crisis: Causes and Lessons Learned: Highlights some of the most prominent factors that contributed to the greatest economic pullback since the Great Depression of the 1930s.

\section{ANAL YSIS}

\section{WHAT IS SUBPRIME MORTGAGE}

A subprime loan is a form of mortgage granted to people with bad credit score scores - 640 or less, and frequently underneath 600 — who, because of their poor credit score histories, could now no longer be capable of qualify for traditional mortgages. There's a big quantity of threats related to any subprime loan. The term subprime itself refers back to the debtors and their 


\section{International Journal of Social Science and Economic Research}

ISSN: $2455-8834$

Volume:06, Issue:06 "June 2021"

financial situation rather than the loan itself. Subprime debtors are much more likely to default than the ones who've better credit score scores. Because subprime debtors give a better threat to lenders, subprime mortgages usually charge interest rates above the prime lending rate. Subprime mortgage interest rates are decided via way of means of numerous special factors: Down payment, credit score, overdue bills, and delinquencies on a borrower's credit report.

\section{TYPES OF SUBPRIME MORTGAGE}

\section{Fixed-Interest Mortgages}

Another sort of subprime loan is a fixed-rate loan, given for a 40- or 50-year term, in evaluation to the usual 30-year length. This prolonged mortgage length lowers the borrower's month-tomonth payments, however, it's far much more likely to be followed through a better interest rate. The interest rates available for fixed-interest mortgages can range considerably from lender to lender.

\section{Adjustable-Rate Mortgages}

An adjustable-rate loan starts with a set interest rate and later, at some point of the existence of the loan, switches to a floating rate. One common instance is the $2 / 28$ ARM. The $2 / 28$ ARM is a 30-12 months loan with a fixed interest rate for 2 years before being adjusted. Another typical version of the ARM loan, the 3/27 ARM, has a fixed interest fee for 3 years before it will become variable. In these styles of loans, the floating rate is decided based on an index plus a margin. A normally used index is ICE LIBOR. With ARMs, the borrower's month-to-month bills are usually lower during the preliminary term. However, while their mortgages reset to the higher, variable fee, loan bills usually increase significantly. Of course, the interest rate could decrease over time, depending on the index and monetary conditions, which, in turn, could reduce the payment amount. ARMs played a big role in the crisis. When home prices started to drop, many house owners understood that their homes were not well worth the amount of the purchase price. This, coupled with the rise in interest rates led to a massive amount of default. This led to a drastic growth in the range of subprime mortgage foreclosures in August of 2006 and the bursting of the housing bubble that ensued the following year.

\section{Interest-Only Mortgages}

The third type of subprime mortgage is an interest-only mortgage. For the initial term of the loan, which is typically five, seven, or 10 years, principal payments are postponed so the borrower only pays interest. He can choose to make payments toward the principal, but these payments are not required. When this term ends, the borrower begins paying off the principal, or he can 


\section{International Journal of Social Science and Economic Research}

choose to refinance the mortgage. This can be a smart option for a borrower if his income tends to fluctuate from year to year, or if he would like to buy a home and is expecting his income to rise within a few years.

\section{Dignity Mortgages}

The dignity loan is a brand new sort of subprime loan, wherein the borrower makes a down payment of approximately $10 \%$ and concurs to pay a higher rate of interest for a fixed period, normally for 5 years. If he makes the month-to-month payments on time, after 5 years, the amount that has been paid toward interest is going in the direction of reducing the balance on the mortgage, and the interest rate is lowered to the prime rate.

The borrowers of subprime loans have certain characteristics in common. These are as follows:

- They usually would have a lower income

- Their credit score would be below 600

- They may have debt-to-income ratio equal to or greater than 0.5

- They would have a poor credit history

- Their credit cards or loan payments would be delayed

- They might have declared bankruptcy once in the past 60 months

- They would have a foreclosure in the past 24 months

- They can also be a new business, retiree or self-employed

\section{STAGES IN THE CREDIT ANALYSIS PROCESS}

The credit score evaluation system is a prolonged one, lasting from some weeks to months. It starts from the information-collection stage up to the decision-making stage while the lender decides whether or not to approve the mortgage application and, if approved, how much credit to extend to the borrower.

The following are the key stages in the credit analysis process:

\section{Information collection}

The first stage in the credit score evaluation method is to accumulate data about the applicant's credit score history. Specifically, the lender is interested in the past repayment report of the customer, organizational reputation, monetary solvency, as well as their transaction records with the financial institution and different monetary institutions. The lender may also assess the ability of the borrower to generate additional cash flows for the entity by looking at how effectively it 


\section{International Journal of Social Science and Economic Research}

ISSN: $2455-8834$

Volume:06, Issue:06 "June 2021"

utilized past credit scores to grow its core business activities. The lender additionally collects data about the purpose of the loan and its feasibility. The lender is interested in understanding if the venture to be funded is feasible and its ability to generate enough cash flows. The credit analyst assigned to the borrower is needed to determine the adequacy of the loan amount to implement the venture to completion and the existence of a good plan to undertake the project successfully. The bank additionally collects data about the collateral of the mortgage, which acts as security for the loan in the event that the borrower defaults on its debt obligations. Usually, lenders prefer getting the mortgage repaid from the proceeds of the venture that is being funded, and only use the security as a fallback on the occasion that the borrower defaults.

\section{Information analysis}

The facts collected in the first stage are analyzed to determine if the information is accurate and truthful. Personal and company documents, such as the passport, corporate charter, trade licenses, corporate resolutions, agreements with clients and suppliers, and different legal documents are scrutinized to determine if they're accurate and genuine. The credit analyst additionally evaluates the monetary statements, which include the earnings statement, balance sheet, cash flow statement, and other related documents to evaluate the monetary capacity of the borrower. The bank additionally considers the experience and qualifications of the borrower in the venture to decide their competence in enforcing the venture successfully. Another aspect that the lender considers is the effectiveness of the venture. The lender analyzes the purpose and future possibilities of the venture being funded. The lender is interested in understanding if the venture is possibly sufficient to provide good enough cash flows to service the debt and pay the operating expenses of the business. A profitable venture will without problems stable credit facilities from the lender. On the downside, if a venture is dealing with stiff competition from different entities or is on a decline, the financial institution can be reluctant to increase credit because of the high possibility of incurring losses on the occasion of default. However, if the financial institution issatisfied that the borrower's level of risk is acceptable, it can extend credit at a high-interest rate to compensate for the high risk of default.

\section{Approval (or rejection) of the loan application}

The final stage in the credit score evaluation method is the decision-making stage. After acquiring and reading the precise financial information from the borrower, the lender decides on whether or not the assessed level of risk is suitable or not. If the credit analyst assigned to the specific borrower is satisfied that the assessed level of risk is acceptable and that the lender will not face any challenge servicing the credit, they'll put up a recommendation file to the credit committee on the findings of the assessment and the final decision. However, if the credit analyst 
unearths that the borrower's level of risk is simply too excessive for the lender to accommodate, they may be required to write down a report to the credit committee detailing the findings on the borrower's creditworthiness. The committee or other appropriateapproval body reserves the final decision on whether or not to approve or reject the loan.

\section{BENEFITS AND LIMITATIONS OF SUBPRIME}

\section{Benefits of a Subprime Loan}

Borrowers with low or poor credit scores can qualify for subprime loans that include many types of loans, such as mortgages and personal loans. A subprime loan can be used to consolidate debt, making payments easier to manage. If borrowers make timely payments on subprime loans, their credit scores might improve. Subprime loans provide opportunities to borrowers to buy homes and other goods that they would not have been able to fund otherwise.

\section{Limitations of a Subprime Loan}

Subprime loans charge higher interest rates to compensate for the higher credit risk.

Higher rates of interest than conventional loans can lead to higher monthly interest payments. Uninformed borrowers are often charged high interest rates and other fees by predatory lenders.

\section{COMPARISON}

\section{WHY INDIA IS THE PERFECT MARKET FOR SUBPRIME LOANS}

India is one of the largest loan-taking countries around the world in 2020 due to the pandemic and the lockdown. Due to covid many people lost their jobs and necessities were also in a dire situation in India so many people opted to take loans but as they were not qualified for the basic loans given by the government they took subprime loans from local lenders. Many of the Indian population nowadays are freelancers and startups who often need funds but don't have any collateral so often they tend to go for the subprime loans rather than the normal loans and have high interest on them.

\section{WHY PEOPLE END TO GO FOR SUBPRIME IN INDIA}

Most freelancers do not have any collateral and do not have proper paperwork for a normal loan so they tend to go for subprime from local vendors with high-interest rates as they knowbanks won't give them proper loans. 


\section{International Journal of Social Science and Economic Research}

Most of the startups have proper paperwork but don't have any good collateral so they tend to take subprime from the banks with higher interest rates as banks or borrowers have a lot of risk going up to $37 \%$ of defaults on startup loans.

Another prominent reason for people opting for subprime on high-interest rates in India is that most people deal in only cash and taking loans from banks is simply not possible for them so they take subprimes to form local lenders with high-interest rate rather than opting for any other type of loan.

\section{GROWING INDIA ECONOMY AND ITS EFFECT ON SUBPRIMES}

As more and more people are getting educated in India and due to its population of around 1.37 billion more and more people wants to be rich and most of the Indian population doesn't have a strong financial background so they do not have the collateral necessary for a normal loan and they also don't have a good credit score as they do not have a steady income so they tend to go with subprime loans with banks or local vendors as they seem fit according to their situation.

\section{HISTORY OF SUBPRIME LENDING}

\section{When did it begin?}

On 15 September 2008, Lehman Brothers [a Wall Street investment bank] filed for bankruptcy. This is generally considered to be the day the economic crisis began in earnest. The thenpresident George W Bush announced that there would be no bail-out. "Lehmans, one of the oldest, richest, most powerful investment banks in the world, was not too big to fail," says the Telegraph.

\section{What caused the 2008 financial crash?}

The 2008 financial crash had long roots but it wasn't until September 2008 that its effects became apparent to the world.

The immediate trigger was a combination of speculative activity in the financial markets, focusing particularly on property transactions - especially in the USA and western Europe - and the availability of cheap credit, says Scott Newton, emeritus professor of modern British and international history at the University of Cardiff.

"There was borrowing on a huge scale to finance what appeared to be a one-way bet on rising property prices. But the boom was ultimately unsustainable because, from around 2005, the gap between incomes and debt began to widen. This was caused by rising energy prices on global 


\section{International Journal of Social Science and Economic Research}

ISSN: $2455-8834$

Volume:06, Issue:06 "June 2021"

markets, leading to an increase in the rate of global inflation.

\section{Lenders To Blame}

Most of the blame is on the mortgage originators or the lenders. That's because they were responsible for creating these problems. After all, the lenders were the ones who advanced loans to people with poor credit and a high risk of default.7 Here's why that happened.

When the central banks flooded the markets with capital liquidity, it not only lowered interest rates, it also broadly depressed risk premiums as investors looked for riskier opportunities to bolster their investment returns. At the same time, lenders found themselves with ample capital to lend and, like investors, an increased willingness to undertake additional risk to increase their own investment returns.

\section{The Bottom Line}

There may have been a mix of factors and participants that precipitated the subprime mess, but it was ultimately human behavior and greed that drove the demand, supply, and investor appetite for these types of loans. Hindsight is always 20/20, and it is now obvious there was a lack of wisdom on the part of many. However, there are countless examples of markets lacking wisdom. It seems to be a fact of life that investors will always extrapolate current conditions too far into the future.

\section{CONCLUSION}

So after my research I would like to conclude that there are a lot of loopholes and faults in the present banking system all over the world and there is no one step one can take to prevent what happened in 2008 and what happened when covid 19 virus hit the world's economy due to the lockdowns. The impact of covid on banking industry is a lot the default rate in india has rose up to $32 \%$ from $24 \%$ most people were not able to pay their monthly or yearly installments on india which also led to $-6.8 \%$ depreciation in india's GDP in 20203 quarter.the crisis in 2008 was caused due to the greedy banks wanting to earn money and the bankers who approved the loans just fee and didn't see the person's credit history one major problem was also the government of united states who did not do anything until the fall happened and the people who knew made a huge profit out of this situation. seeing india through that eyes of a economist today we can safely say that we are way secure as many people in india still don't believe in taking loans and the default ratio is also quiet low compared to what the situation was in us when the crisis happened but this doesn't mean that the crisis could not happen in india if we do not take safe steps india banks should have economy shutdown in 1015 years ahead of this newsletter.But 


\section{International Journal of Social Science and Economic Research}

ISSN: $2455-8834$

Volume:06, Issue:06 "June 2021"

taking precautions and making our banking system synchronised with the government will help in avoiding such crisis. although india is the right market for subprime loans as most people don't have good credit scores because of their family background and because many people in india are getting educated and have a lot of new business ideas which need funding and due to their low income they need to take loans and have to go with subprime market.so overall india is a large market for these subprime loans and the indian government and rbi should maintain a proper record for such loans and their default rate otherwise there will be an crisis in india just like united states.

\section{ACKNOWLEDGMENT}

I'd like to use this occasion to show my heartfelt thanks and respect for my mentor, Mr vijay khannah for his exceptional direction, monitoring, and ongoing encouragement over the duration of our project The blessings, assistance, and direction that he has provided me from time to time will go me a long way on the life path that I am about to go on.

\section{Bibliography}

1. Federal Reserve History. "Subprime Mortgage Crisis." Accessed April17, 2020

2. European Central Bank. "The first twenty years of the European Central Bank:monetary policy," Page 15. Accessed April 15, 2020.

3. The causes of supreme crisis Accessed April 21, 2020

4. Startups target subprime customers, riding on India's fintech boom Accessed april24,2020

5. Subprime Lender Accessed April 19, 2020

6. What Was the Subprime Meltdown? Accessed April17, 2020

7. What is the Credit Analysis Process? Accessed April26, 2020

8. The Risk of Subprime Mortgages by a New Name Accessed April30, 2020

9. What is a Subprime Loan? Accessed April 18, 2020

https://www.investopedia.com/articles/07/subprime-blame.asp

https://www.thebalance.com/subprime-mortgage-crisis-effect-and-timeline-3305745 
International Journal of Social Science and Economic Research

ISSN: $2455-8834$

Volume:06, Issue:06 "June 2021"

https://www.thebalance.com/what-caused-the-subprime-mortgage-crisis-3305696

https://www.techinasia.com/lending-to-subprime

https://www.investopedia.com/terms/s/subprimelender.asp\#: :text=Subprime $\% 20$ lending $\% 2$

0is\%20the\%20practice,carry\%20above\%2Daverage\%20interest\%20rates.

https://www.investopedia.com/terms/s/subprime-meltdown.asp

https://corporatefinanceinstitute.com/resources/knowledge/credit/credit-analysis-process/

https://www.investopedia.com/ask/answers/07/subprime-mortgage.asp

https://lawshelf.com/videocoursesmoduleview/the-subprime-mortgage-crisis-causes-and-les

sons-learned-module-4-of-5/

https://corporatefinanceinstitute.com/resources/knowledge/credit/subprime-loan/

https://www.financialexpress.com/industry/banking-finance/share-of-subprime-credit-borrowe rsrise-to-32/1750121/

https://m.rbi.org.in/scripts/bs viewcontent.aspx?Id=1988 